\title{
Familial pulmonary stenosis with underdeveloped or normal right ventricle
}

\author{
T. Klinge and H. Baekgaard Laursen \\ From the Departments of Paediatrics and Cardiology, \\ University Hospital, Aarhus, Denmark
}

A family with 3 cases of pulmonary stenosis with underdeveloped or normal right ventricle is described. In the family there have also been some spontaneous abortions and many infant deaths, and it seems possible that these were also related to congenital cardiac abnormalities. Recognized syndromes with pulmonary stenosis and reports on familial occurrence of this malformation are reviewed. The cases reported in this paper differ from these previously described syndromes. The possibility of sex-influenced monogenic inheritance is discussed.

The aetiology of congenital malformations of the heart is largely unknown. It is recognized that genetic factors are responsible for about ro per cent of all malformations, chromosomal aberrations for about 5 per cent, and environmental factors for about ro per cent, leaving 75 per cent of cases with no apparent cause (Rowe and Mehrizi, 1968). In order to gain further knowledge of inheritance mechanisms in congenital heart disease, it is useful to draw attention to familial forms of congenital heart disease, seldom or not previously described. We have had the opportunity of studying a family in which three children had pulmonary stenosis with underdeveloped or normal right ventricle.

\section{Case reports}

The pedigree of the family is shown in Fig. I. The propositus is III-20. We were informed that there had been many infant deaths on the paternal side of the family (II-3, II-4, II-8, III-12, and III-17), and that at least two of these infant deaths had occurred because of congenital heart malformations (III-I2 and III-I7).

\section{III-20 (Fig. 2)}

A girl born in October 1972, the second of two sibs. A sister, older by one year, is healthy. The mother had a spontaneous abortion in the third month of a previous pregnancy. The father was 35 years and the mother 33 years old. Pregnancy was uncomplicated. In the neonatal period there was respiratory insufficiency with cyanosis and feeding difficulties.

Clinical examination showed a dysmature infant with a short neck, a broad forehead, and severe myopia. There was a high-frequency, grade 3 systolic murmur with maximum intensity in the left third intercostal space at the sternal border. The murmur was heard in the neck and on the back. Electrocardiogram showed left anterior hemiblock. Radiography of the thorax revealed no enlargement of heart shadow and slightly decreased pulmonary vascular markings. There were no signs of heart failure. The psychomotor development was somewhat retarded, and an ophthalmological examination revealed a very serious myopia.

When the patient was 4 months old cardiac catheterization was performed. This revealed a common atrioventricular canal with a slight pulmonary stenosis and an underdeveloped right ventricle (Table I).

Since then the psychomotor development has been delayed. At 3 months she could fix on objects for short periods, and at 6 months she could look at her hands, follow objects near her eyes, and gain visual contact with others. At 9 months of age she was not yet able to sit alone. She thrived well for the first 6 months, but then began regurgitating and vomiting. Therefore, she was readmitted at the age of 8 months for further investigation. Chromosome analyses showed a normal female karyotype, and other investigations revealed no significant abnormalities.

\section{III-12}

A girl born in June 1967, the first of 3 sibs. Two boys are healthy. The mother had previously had 3 spontaneous abortions in the third month of pregnancy. The pregnancy was uncomplicated. The full-term infant was cyanotic and flaccid and had a heart murmur. Electrocardiogram showed prominent $\mathbf{P}$ waves and a normal axis without hypertrophy. Radiography of the thorax revealed a large heart with a concave pulmonary segment and decreased pulmonary vascularity. The infant could not suck and was in a poor condition. She died at the age of 12 days. Her weight was then $1860 \mathrm{~g}$. 


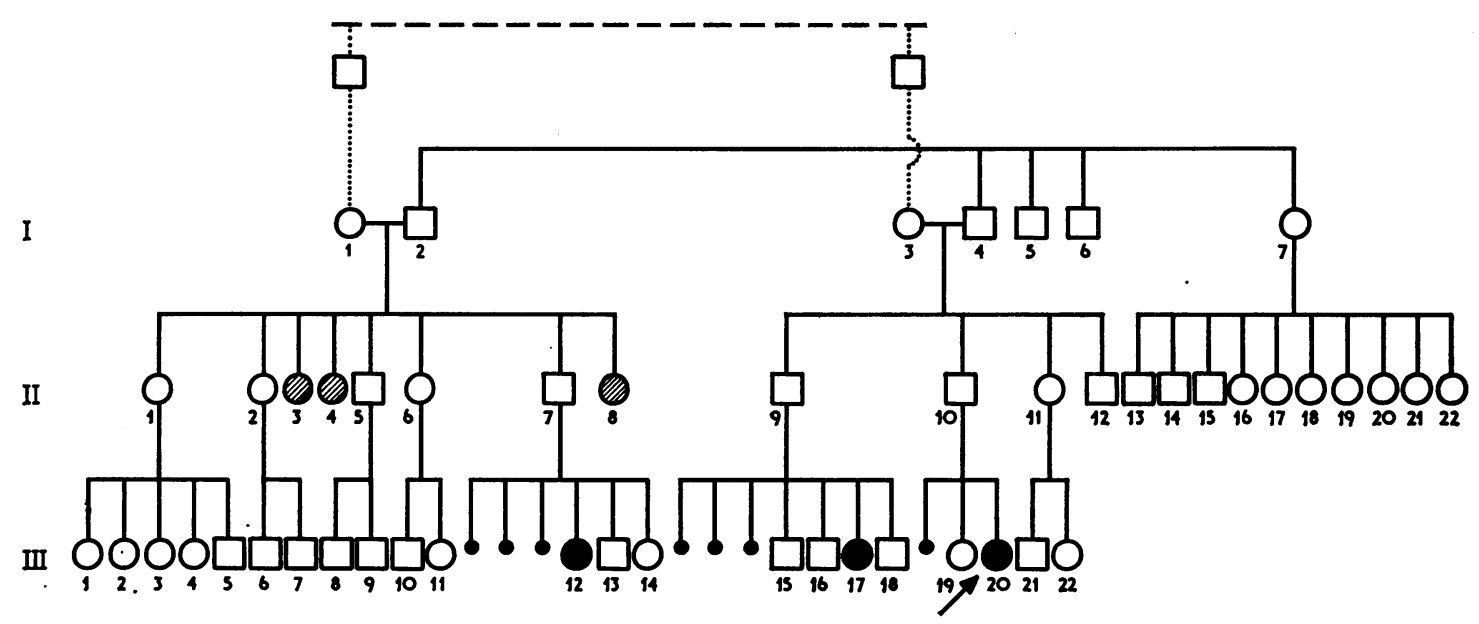

$\square$ Male $\bigcirc$ female Female, pulmonary stenosis with underdeveloped or normal right ventricle $\bullet$ Abortus
Female, deceased in infancy

FIG. I Pedigree.

Necropsy Heart $3.5 \times 3.5 \mathrm{~cm}$, right ventricular wall $0.5 \mathrm{~cm}$, left ventricular wall $0.5 \mathrm{~cm}$. Hypoplastic right ventricle, considerable valvular pulmonary stenosis. No septal defects. No persistent ductus. Kidneys normal.

\section{III-I7 (Fig. 3)}

A girl born in July 1962, paternal cousin to the propositus, was the third of 4 sibs. Two older and a younger brother are healthy. The mother had 3 spontaneous abortions. Pregnancy was uncomplicated. Delivery 2 weeks after term. During the following months she had

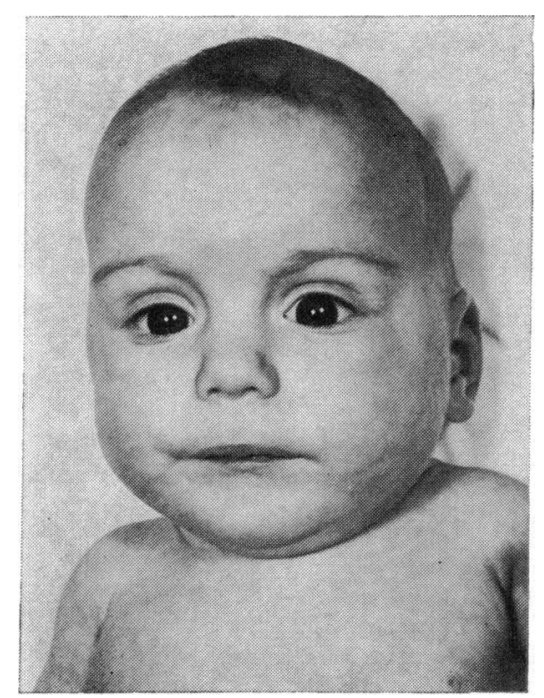

FIG. 2 Patient III-20, 4 months old. upper respiratory tract infections, regurgitation, vomiting, and unsatisfactory weight gain.

At 5 months she was noted to be a small, thin girl with light, thin hair and hypertelorism. Clinical examination revealed a low-frequency, grade 3 systolic murmur with maximum intensity in the left second intercostal space at the sternal border and a faint and short diastolic murmur at the lower left sternal border. She became cyanotic when crying. No signs of cardiac failure. Electrocardiogram showed right ventricular hypertrophy. Radiography of the thorax revealed a decreased pulmonary vascularity and an enlarged right ventricle. Cardiac catheterization at the age of 8 months revealed slight valvular pulmonary stenosis and an atrial septal defect with a moderate left-to-right shunt (Table I). The heart abnormalities were not considered to be the cause of her failure to thrive. Other conditions such as progeria or some metabolic defect were considered, but no definite diagnosis could be made.

Subsequently her condition remained unchanged. Her motor development was greatly retarded. She could follow her surroundings with her eyes when 8 months old, but not sit alone, and hardly lift her head when lying prone. Reflexes and muscular tone were normal. Her appearance, however, was senile. She died at the age of Io months, a few hours after a sudden generalized seizure with cyanosis.

Necropsy suggested subacute glomerulonephritis. There was an ostium secundum atrial septal defect, bicuspid pulmonary valves with thickened edges, a slight displacement of the coronary artery ostia, and a bicuspid aortic valve. Her weight was $3600 \mathrm{~g}$.

\section{II-8}

A girl born in September 1946, the last of 8 sibs. Birthweight $1800 \mathrm{~g}$. When 3 months old she weighed $3500 \mathrm{~g}$. 
TABLE I Results of heart catheterization performed in 2 patients

\begin{tabular}{llllllll}
\hline Patient & \multicolumn{2}{l}{ Pressures $(\mathrm{mmHg})$} & & & \multirow{2}{*}{ Angiocardiography } & Shunt \\
\cline { 2 - 6 } & $P A$ & $R V$ & $R A$ & $L A$ & $L V$ & \\
\hline III-20 & $17 / 9$ & $39 / 0-8$ & $0-8$ & $7 / 0-6$ & $72 / 0-6$ & + & $\begin{array}{c}\text { Moderate left to right between } \\
\text { ventricles }\end{array}$
\end{tabular}

Diagnosis: slight valvular pulmonary stenosis; underdeveloped right ventricle; common atrioventricular canal

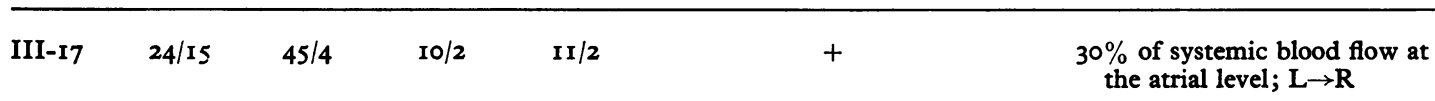

Diagnosis: slight valvular pulmonary stenosis, normal right ventricle; small atrial septal defect

PA: pulmonary artery pressure; RV: right ventricular pressure; RA: right atrial pressure; LA: left atrial pressure; LV: left ventricular pressure; $L \rightarrow R$ : left-to-right shunt.

She was admitted to the local hospital in May 1947, when her weight was $2700 \mathrm{~g}$. She regurgitated, vomited, and sucked poorly. She had many upper respiratory tract infections, and at the age of 9 months she died suddenly. Weight $3750 \mathrm{~g}$, length $61 \mathrm{~cm}$. There was no necropsy.

\section{II-4}

A girl born in May 1935, the fourth of 8 sibs. Birthweight $2000 \mathrm{~g}$. Died in November 1935. She then weighed 3500 g. No necropsy.

\section{II-3}

A girl born in September 1931, the third of 8 sibs. Birthweight $2250 \mathrm{~g}$. Admitted to the local hospital in March

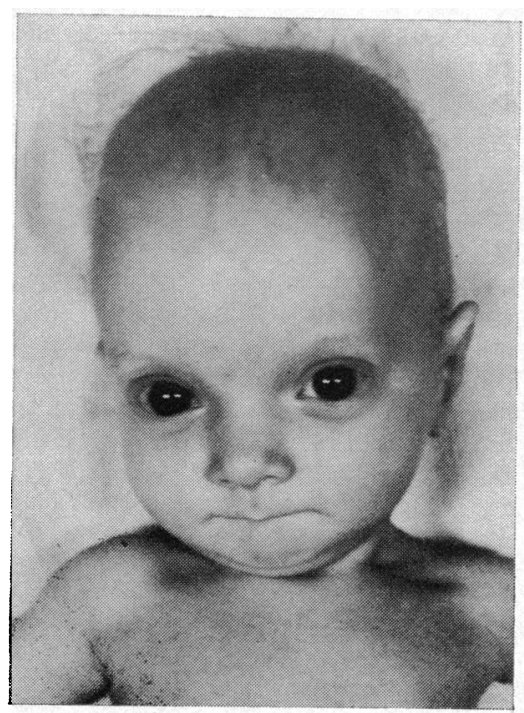

FIG. 3 Patient III-I7, 5 months old.
1932. Vomited much and cried much. Died in May 1932 She then weighed $3500 \mathrm{~g}$. No necropsy.

\section{Discussion}

Pulmonary stenosis or atresia without ventricular septal defect may occur with underdevelopment of the right ventricle. There is a wide spectrum of anatomical and functional disorders (Williams, Barratt-Boyes, and Lowe, 1963), taking into account the various types and degree of right ventricular outflow obstruction and various degrees of development of the right ventricle.

In pulmonary atresia with intact ventricular septum the right ventricle is small in 80 per cent of the cases (Rook and Gootman, 197r ; Miller et al., 1973). This severe and relatively uncommon anomaly was reviewed by Gersony et al. (1967), based upon 123 cases reported up to 1967. The incidence of this anomaly among the newborn with congenital heart disease seems to be under I per cent (Campbell, 1973).

Isolated underdevelopment of the right ventricle without infundibular or valvular stenosis is very uncommon (Hollman, 1968). Another variety of this lesion is Uhl's anomaly with congenital absence of the myocardium of the right ventricle (Díaz et al., 1973).

Pulmonary stenosis and/or infundibular stenosis with a normal or hypertrophic right ventricle is a common congenital anomaly comprising about 6.9 per cent of all cardiac malformations at birth (Campbell, 1973). Whether the combination of abnormalities mentioned represents varying degrees of a common developmental disorder is as yet unknown. The occurrence of a spectrum of cases in the same family might support such a view. 
TABLE 2 Comparison of findings in 6 patients of same family

\begin{tabular}{|c|c|c|c|c|c|c|}
\hline Patient & $I I I-20$ & $I I I-12$ & $I I I-I 7$ & $I I-8$ & $I I-4$ & $I I-3$ \\
\hline Sex & $\mathrm{F}$ & $\mathrm{F}$ & $\mathrm{F}$ & $\mathrm{F}$ & $\mathrm{F}$ & $\mathbf{F}$ \\
\hline Pregnancy & Normal & Normal & Normal & - & - & - \\
\hline $\begin{array}{l}\text { Delivery } \\
\text { Birthweight }\end{array}$ & I week before term & At term & 2 weeks after term & At term & - & 一 \\
\hline (g) & 2100 & 2150 & 2200 & 1800 & 2000 & 2250 \\
\hline \multicolumn{7}{|l|}{ Birth length } \\
\hline (cm) & 47 & 47 & 48 & - & - & 一 \\
\hline $\begin{array}{l}\text { Condition } \\
\text { at birth }\end{array}$ & $\begin{array}{l}\text { Flaccid, respiratory } \\
\text { insufficiency }\end{array}$ & Flaccid, cyanotic & Normal & - & - & - \\
\hline Thriving & Good & - & Poor & Poor & Poor & Poor \\
\hline Heart & $\begin{array}{l}\text { Slight valvular } \\
\text { pulmonary stenosis, } \\
\text { underdeveloped } \\
\text { right ventricle, } \\
\text { common atrio- } \\
\text { ventricular canal }\end{array}$ & $\begin{array}{l}\text { Considerable valvular } \\
\text { pulmonary stenosis, } \\
\text { hypoplastic right } \\
\text { ventricle }\end{array}$ & $\begin{array}{l}\text { Slight valvular } \\
\text { pulmonary stenosis, } \\
\text { small atrial septal } \\
\text { defect, normal } \\
\text { right ventricle }\end{array}$ & 一 & - & - \\
\hline Eyes & Myopia, big cornea & - & Big cornea & - & - & 一 \\
\hline Skull & $\begin{array}{l}\text { Broad forehead, } \\
\text { large fontanelles }\end{array}$ & $\begin{array}{l}\text { Large fontanelles, } \\
\text { wide sutures }\end{array}$ & Normal & $\begin{array}{l}\text { Large } \\
\text { fontanelles }\end{array}$ & - & - \\
\hline \multicolumn{7}{|l|}{$\begin{array}{l}\text { Psychomotor } \\
\text { develop- }\end{array}$} \\
\hline ment & Retarded & - & Retarded & Retarded & - & - \\
\hline $\begin{array}{l}\text { Weight and } \\
\text { length at } \\
\text { death }\end{array}$ & - & $\begin{array}{l}1860 \mathrm{~g} \\
46 \mathrm{~cm}\end{array}$ & $\begin{array}{l}3600 \mathrm{~g} \\
57 \mathrm{~cm}\end{array}$ & $\begin{array}{l}3750 \mathrm{~g} \\
61 \mathrm{~cm}\end{array}$ & $\underline{3500 \mathrm{~g}}$ & $3500 \mathrm{~g}$ \\
\hline Age at death & - & $12 \mathrm{dy}$ & $9 \mathrm{mth}$ & $9 \mathrm{mth}$ & $6 \mathrm{mth}$ & $7 \mathrm{mth}$ \\
\hline
\end{tabular}

The familial occurrence of pulmonary stenosis is not common. McKeown, MacMahon, and Parsons (I953), analysing the familial incidence of congenital malformations of the heart, found no cases of congenital heart disease in 21 subsequent sibs after 20 first propositi with pulmonary stenosis. Lamy, de Grouchy, and Schweisguth (1957) found 4 cases of congenital heart disease among 107 sibs of 56 patients with pulmonary stenosis (I case of pulmonary valvular stenosis, I case of Fallot's tetralogy, and 2 cases with unspecified congenital heart disease). Rowe and Mehrizi (1968) mention a twin pair, in whom I had pulmonary stenosis with intact interventricular septum (the size of the right ventricle is not mentioned) and the other moderate pulmonary stenosis with normal ventricular size. Familial supravalvular aortic and pulmonary stenosis (presumably a different entity from that under discussion) was studied in 3 families by Kahler et al. (1966). The authors suggested possible inheritance by an autosomal dominant, non-sex-linked transmission with variable expression.

Pulmonary stenosis may also be seen in connexion with certain syndromes known to be genetically determined, e.g. trisomy-18, Marchesani's syndrome, Noonan's syndrome, and the cardiofacial syndrome (Linde, Turner, and Sparkes, 1973).

Our 3 patients (III-20, III-I2, and III-I7) have varying pictures of pulmonary stenosis and underdeveloped right ventricle. Unfortunately, no information is available concerning possible congenital heart disease in the 3 earlier infants who died (II-8, II-4, and II-3), but the clinical picture, as far as it can be estimated in retrospect, shows some similarities to that of our patients (Table 2). Furthermore, there have been many spontaneous abortions in the family. This suggests a familial occurrence of a syndrome characterized by psychomotor retardation, pulmonary stenosis, and possible underdevelopment of the right ventricle. This picture is not identifiable with any of the syndromes with pure pulmonary stenosis previously described.

With respect to the mode of inheritance nothing definite can be said. It is worthy of note that I-I and I-3 are cousins, but an autosomal recessive mode of inheritance is not likely, as this would mean that the 3 women married to II-7, II-9, and II-Io must be carriers, which is unlikely as they are unrelated. The fact that all the 6 family members who presumably had the disease are female, rules out an X-linked recessive mode of inheritance. This fact also speaks against an autosomal dominant mode of inheritance, though this cannot be definitely ruled out if it is supposed that II-7, II-9, and II-Io carry the gene in non-penetrant form. This again is not very likely. One mode of inheritance, i.e. sex-influenced mono- 
genic inheritance fits all the facts, if it is supposed that the gene is dominant in females, recessive in males.

We wish to thank Professor A. J. Therkelsen, Institute of Medical Microbiology, University of Aarhus, Denmark, for analysing the pedigree of the family with respect to the mode of inheritance.

\section{References}

Campbell, M. (1973). Incidence of cardiac malformations at birth and later, and neonatal mortality. British Heart fournal, 35, 189.

Díaz, L. P., Jiménez, M. Q., Granados, F. M., Martínez, V. P., and Batres, G. M. (I973). Congenital absence of myocardium of right ventricle: Uhl's anomaly. British Heart fournal, 35, 570 .

Gersony, W. E., Bernhard, W. F., Nadas, A. S., and Gross, R. E. (1967). Diagnosis and surgical treatment of infants with critical pulmonary outflow obstruction. Circulation, 35, 765 .

Hollman, A. (1968). Underdevelopment of the right ventricle. In Pediatric Cardiology, p. 501. Ed. by Hamish Watson. Lloyd-Luke, London.

Kahler, R. L., Braunwald, E., Plauth, W. H., and Morrow, A. G. (1966). Familial congenital heart disease. American fournal of Medicine, 40, 384 .
Lamy, M., de Grouchy, J., and Schweisguth, O. (1957). Genetic and non-genetic factors in the aetiology of congenital heart disease: a study of 1188 cases. American fournal of Human Genetics, 9, 117.

Linde, L. M., Turner, S. W., and Sparkes, R. S. (1973). Pulmonary valvular dysplasia. A cardiofacial syndrome. British Heart fournal, 35, 301 .

McKeown, T., MacMahon, B., and Parsons, C. G. (1953). The familial incidence of congenital malformation of the heart. British Heart fournal, 15, 273.

Miller, G. A. H., Restifo, M., Shinebourne, E. A., Paneth, M., Joseph, M. C., Lennox, S. C., and Kerr, I. H. (1973). Pulmonary atresia with intact ventricular septum and critical pulmonary stenosis presenting in the first month of life. Investigation and surgical results. British Heart fournal, 35, 9.

Rook, G. D., and Gootman, N. (197I). Pulmonary atresia with intact interventricular septum operative treatment with survival. American Heart fournal, 81, 476.

Rowe, R. D., and Mehrizi, A. (I968). The Neonate with Congenital Heart Disease, p. 275. W. B. Saunders, Philadelphia, London, and Toronto.

Williams, J. C. P., Barratt-Boyes, B. G., and Lowe, J. B. 61963). Underdeveloped right ventricle and pulmonary stenosis. American fournal of Cardiology, 11, 458.

Requests for reprints to Dr. H. Baekgaard Laursen, Department of Cardiology, University Hospital, 8000 Aarhus C, Denmark. 